\title{
The EU Policy to Attract Highly Skilled Workers: The Status of Implementation of the Blue Card Directive
}

\author{
Marco Mazzeschi ${ }^{1}$ \\ ${ }^{1}$ Independent Researcher, Italy \\ Correspondence: Marco Mazzeschi, Italian Lawyer, Admitted to Milan and Taipei Bar Associations, Owner of \\ Mazzeschi Srl, Italy. E-mail: mm@mazzeschi.it
}

Received: October 17, 2016

Accepted: November 3, 2016 Online Published: November 25, 2016

doi:10.5539/jms.v6n4p45

URL: http://dx.doi.org/10.5539/jms.v6n4p45

\begin{abstract}
A worldwide shortage of about 38-40 million highly skilled workers is forecast by 2020 . Many countries are implementing policies to attract workers with special skills and knowledge. What is the European Union doing to face this challenge? In 2009 the EU adopted the so called Blue Card Directive (n. 2009/50) to attract highly qualified workers from abroad, address labour and skills shortages and strengthen the EU's competitiveness and economic growth. The Directive was implemented by most EU countries during 2012 but has proven to be insufficiently attractive and underused, with only a limited number of Blue Cards issued. For these reasons, the EU Commission has announced some proposed changes to the Blue Card Directive. The specific objectives are, amongst other things, to increase the numbers of third-country highly skilled workers immigrating to the EU and simplify and harmonise admission procedures for third-country highly skilled workers.
\end{abstract}

The article also outlines a summary of the current state of implementation of the Directive in the following countries: Italy, France, Spain, Germany, Poland, Hungary, Austria, Belgium and The Netherlands.

Keywords: immigration, European Union, highly skilled workers

\section{Introduction}

The International Organization for Migration (IOM) published in December 2014 an overview on global migration trends. The paper reports some interesting data and information. The report forecasts that: (a) by 2020, there will be a 38-40 million potential shortage of workers with tertiary education (13\% of demand), 45 million too few workers with secondary education in developing countries, and 90-95 million more low-skill workers than employers will need (11\% oversupply; Ibid.); (b) the gap between demand and supply of high-skill workers is estimated to be equivalent to 16-18 million workers in advanced economies, 23 million in China. The total shortage for medium-skilled workers for the next 20 years is estimated at 45 million workers, 10 million in India, and 31 million in Young Developing economies.

According to the OECD International Migration Outlook 2015, a number of OECD countries have fundamentally revised their migration legislation in the past few years, most changes tend towards restrictions against immigration. On the other hand the report indicated that skilled workers are still wanted, but countries are picking them more selectively and investors and enterpreneurs are sought after, but are increasingly scrutinized.

\section{Policies to Attract Highly Skilled Workers in the EU}

What is the European Union (EU) doing in order to attract highly skilled workers? In 2009 the EU enforced the so call Blue Card Directive (EU directive 2009/50 of May 29, 2009). The main goal and objective of the Directive was to attract highly qualified workers from abroad, address labour and skills shortages and strengthen the EU's competitiveness and economic growth.

The main requirements to obtain a Blue Card permit, according to article 5 of the Directive are: (i) a work contract or binding job offer with a salary of at least 1.5 times the average gross annual salary paid in the Member State concerned (Member States may lower the salary threshold to 1.2 for certain professions where there is a particular need for third-country workers); (ii) for regulated professions, documents establishing that the worker meets the legal requirements of the country; (iii) for unregulated professions, documents establishing the relevant higher professional qualifications. Higher professional qualifications can be attested by a higher education qualification 
(i.e., diploma attesting the completion of a post-secondary higher education program of at least three years) or by having at least five years of professional experience in a level comparable to higher education qualifications and which is relevant in the position offered in the job contract.

The EU realized that it had to compete for a global pool of talent with a growing number of other destinations. The EU Blue Card scheme has however proven to be insufficiently attractive and underused, with only a limited number of Blue Cards issued. Restrictive admission conditions and the existence of parallel rules, conditions and procedures across the EU are creating a burden for employers and applicants and have limited the use of the scheme.

The Communication from the EU Commission to the EU Parliament of May 22, 2014 on the implementation of the Blue Card Directive, outlines some statistics which point to low rates of use of the Blue Card scheme, as in 2012, only 3,644 Blue Cards were granted. In 2013, this number rose to 15,261. The report also pointed to a fragmented implementation of the directive. The data showed that in both years, the majority of all Blue Cards were awarded in Germany: 70,5\% in 2012 and 75,8 \% in 2013. Most Blue Card holders come from Asia, particularly India and China. However no specification of the sector of the employment of Blue Card holders was provided.

In the future, structural changes in the EU's economies will continue to increase the demand for higher skills that are not immediately available in the labour market, creating further skills shortages that cannot be filled by the existing EU workforce. For example, in the ICT sector, 756.000 unfilled vacancies for highly skilled ICT professionals are expected by 2020. In the health sector, a shortfall of around 1 million highly skilled workers is estimated by 2020 which means that around $15 \%$ of total care would not be covered compared to 2010 .

\section{EU Commission's Proposed Changed to the Blue Card Directive}

For these reasons, the EU Commission has announced some proposed changes to the Blue Card Directive. The specific objectives are to: (i) develop a coherent approach and common immigration policy on third-country highly skilled third country nationals; (ii) increase the numbers of third-country highly skilled workers immigrating to the EU; (iii) simplify and harmonise admission procedures for third-country highly skilled workers; (iv) promote third-country highly skilled workers' social and economic integration, including labour market integration, and rights; (v) foster intra-EU mobility, remove unnecessary barriers and allow a more efficient allocation of third country highly skilled workers through the EU; (vi) further develop and capitalize on the "EU Blue Card" brand in order to improve the image of the EU as an attractive destination; (vii) if the EU added-value is proven, consider developing a coherent approach and common immigration policy on third-country highly skilled business persons and entrepreneurs who are willing to invest in Europe and/or service providers.

\section{Status of Implementation of the Directive}

The Directive was to be transposed in the national legislation by each Member State by June 19, 2011. The UK, Ireland and Denmark opted out of the Directive and therefore the relevant provisions do not apply to these States. Below is a summary of the current status of the implementation of the Directive in some of the most important EU countries.

\section{Italy}

Since its implementation, Italy has issued a limited number of Blue Card permits, namely 6 in 2012, 87 in 2013 and 165 in 2014. In Italy the minimum salary threshold is quite low, approximately $€ 25,000 /$ year. Despite the fact that the local hiring of non EU workers is subject to quota limitations (quotas should be issued by the Government every year, but their allocation is quite unpredictable) and therefore is quite difficult for Italian companies to obtain work permits for non EU workers, Blue Cards have not been very popular so far and many immigration offices are still reluctant to issue these kind of permits. One of the hurdles to a more widespread implementation is due to the fact that a pre-condition to the application is the obtainment of the recognition of the professional and academic qualifications by the Italian Consulates abroad ("Dichiarazione di valore"). Requirements and processing time vary depending upon each Consulate and some Consulates are quite strict in terms of the documents requirement. Once this step is accomplished, processing time varies depending upon the Immigration Office where application is filed, but can be from 1 to 5 months.

\section{France}

In France, the minimum salary threshold is $€ 53,837 /$ year. The transposition into French law of the Directive was done following the guidelines of the Directive. The procedure has proven to be efficient and the only difficulties experienced are due to some delays in obtaining the clearance by the competent authorities on professional and 
academic qualifications. The Blue Card is extensively used by French companies, especially due to: (i) the fact that authorities are becoming stricter on criteria for the issuance of work permits for intra-company and highly skilled workers, and that (ii) the Blue Card permit can be used for the purpose of obtaining permanent residency contrary to the intra-company permit. On the other hand, it is quite difficult for an individual already working in France under a different status, to change his status and obtain a Blue Card permit.

\section{Spain}

In Spain, the minimum salary must be at least 1.5 times the minimum salary set by the Spanish National Statistics Institute (INE) for the employer's National Classification of Business Activities code (CNAE) (approx. $€ 34,000$ ). It is mandatory to have a 3 year- university degree (for the fast track 4 year university degree or 3 year postgraduate are required) o a minimum of 5 year- professional experience (that can be compared to the academic qualification). The processing time depends on the organ where the application is submitted. If the application is filed through the fast track, it takes 1 month. If the application is submitted through the local immigration office, it takes 45 days. On the other hand, the application is submitted to either the local immigration office or through the fast track in Spain depending on the characteristics of the Spanish company. These organs do issue the work and residence permits, and once notified, the consulates do process the visa application upon submission by the assignee. The blue card scheme was very successful until September 2013 when the Entrepreneur's Act (Act 14/2013) came into force. From that moment, the blue card is very seldom used. For skilled workers, the most beneficial scheme is the single permit for higly qualified workers regulated by the Act 14/2013. This permit represents additional benefits regarding timelines, process and requirements for qualification and salary. The submission of the Blue card application through the local immigration office can be subject to the labor market test except for some cases stipulated in the immigration Act. It is worthy to indicate that the family dependants of a blue card holder, of legal age, have the right to work.

\section{Germany}

Germany has re-launched in 2013 a major part of its employment migration law and introduced the EU Blue Card as the main residence title for highly qualified migration. Accordingly, numbers are constantly rising. A total of 14,468 Blue Cards have been issued in 2015. Between January and March 2016, 4,333 Blue Cards have been issued, which is a rise of $15 \%$ in comparison to the same timespan in 2015. Looking at the persons obtaining Blue Cards, they can be identified by nationalities as being mostly Indian nationals ( 21.1 per cent) followed by Chinese (8.5 per cent), Russians (7.5 per cent), Nationals of Ukraine (5.3 per cent) and Syria / Arab Republic ( 4.9 per cent).

The minimum salary threshold for the EU Blue Card in 2016 has been EUR 4,134 per month. For shortage profession, the reduced threshold amounts to EUR 3,224. A rise of these thresholds is expected in January 2017. Validation of the diplomas is not difficult and can either be done by matching the diploma to a database provided by the Länder or-if the diploma does not match — by a validation process. The validation process takes an average of 2 to 4 weeks and a fee of EUR 200 applies.

The Blue Card is quite popular with applicants as it provides a fast track route into German permanent residency. However, as it requires a local employment in Germany, many authorities deny issuing a Blue Card if the applicant is still tied to a dormant employment agreement abroad.

\section{The Netherlands}

In The Netherlands, the Blue Card permit is not very popular. In 2012 only 10 Blue Cards have been granted, in 2011 only three. More recent information is not available, but the numbers haven't risen drastically. The reason for lack of significant use of the Blue Card option in The Netherlands is that it is not attractive in comparison to the Highly Skilled Migrant Scheme (around 10,000 applications per year).

The minimum salary threshold for the EU Blue Card is EUR 4.968 per month (excluding the required holiday allowance of $8 \%$ ). The diploma validation is not a real obstacle; it is done by a government organisation (IDW). Validation can be done with copy of the diploma and the transcripts. Validation takes two weeks. Depending on the country were the diploma was obtained, additional requirements might be applicable.

The reason the Highly Skilled Migrant Scheme is more popular is the lower and more differentiated wage threshold ( $€ 2.228$ to $€ 4.240$ per month). Also the documents required for an application under the Highly Skilled Migrant Scheme are less burdensome (for example, no diploma and diploma validation is required).

\section{Belgium}

In Belgium, the threshold (2016) for the annual gross salary has been set at 51,494 EUR. This amount is updated every year by means of an index-linking: the next update will take effect on 1 January 2017. The employee must be the holder of a degree from a higher education institution, which is recognized as such in its country. The 
degree can be a degree, certificate or other document confirming that a higher education program with a duration of at least three years has been successfully completed. Professional qualifications are not taken into account. The Blue Card has not become a success in Belgium: only very few applications have been filed since 2012. If both the conditions for obtaining a temporary employment authorization in the framework of the Blue Card and the conditions for obtaining an employment authorization for highly skilled workers in the framework of the work permit B are fulfilled, the employer can choose which option to follow. In practice, employers prefer to apply for a highly skilled work permit B because of the lower threshold (39,824 EUR for 2016) and the faster processing time (two to three weeks).

\section{Austria}

In Austria the major prerequisites of an EU Blue Card are: (i) an Austria-based employer; (ii) a 3 year university degree obtained at a recognized institution validated by the Ministry of Education: validation usually takes 2-3 weeks; (iii) compatibility of university education and previous professional experience with the envisaged employment in Austria. Compatibility is assessed with a text which can be quite rigid; (iv) an annual gross salary which equals or exceeds $150 \%$ of the average annual gross salary for full-time employees in Austria (in 2016: EUR 58,434); and (v) a favorable labor market test result confirming that no similarly qualified Austrian or EU citizen can fill the position.

As opposed to other combined residence and work permits (for example Red-White-Red Cards for highly skilled employees and skilled employees in shortage professions, which are valid for up to one year), EU Blue Cards are issued for a period of two years. Applicants for EU Blue Cards are exempt from adducing proof of a legal claim to accommodation in line with local standards in Austria. Blue Card application can be applied for by authorized representatives of employers. After havingcarried out a preliminary assessment this immigration authority forwards the application to the labour market authority. Once the market test is passed and the remaining employment related requirements are met, the application is returned to the immigration authority for the issuance of the EU Blue Card. Except for Vienna, Austrian immigration authorities usually manage to comply with the statutory processing deadline of eight weeks (from the day of the filing of a complete application). In view of the above Red-White-Red Card schemes for (highly) skilled third country nationals, EU Blue Cards have so far only been of limited significance for corporate migration to Austria. Between 1 January and 30 September 2016, 784 Red-White-Red Cards for (highly) skilled employees were issued, but only 100 EU Blue Cards.

\section{Poland}

In Poland, the Blue Card is not very popular: in 2012, only 2 Blue Cards were issued, 16 in 2013 and 45 in 2014. Even through the Blue Card is more beneficial for its holder than a standard residence permit based on work, these numbers - comparing to other EU countries - are still quite small. The most important benefits of obtaining the Blue Card, as opposed to regular residence permit, include: (i) possibility to stay in Poland up to 3 months in the case of temporary unemployment; (ii) change of remuneration, the employment position or even employer does not require applying for a change of the Blue Card after 2 years of the employee's stay in Poland on the basis of the Blue Card (the employee must still notify the authorities of the change); (iii) periods of stay in other EU countries on the basis of the EU Blue Card count towards the 5-year required period of stay in Poland for the purpose of obtaining long-term resident status (iv) under certain conditions family members are exempted from the obligation to obtain work permits.

On the other hand, the Blue Card applicants must meet the same conditions as in case of regular work. This is probably the reason why the Blue Card is not popular in Poland. The conditions of obtaining the Blue Card are the following: (1) high professional qualifications of the applicant-i.e., an academic degree obtained during at least 3-year academic course or at least a 5-year professional experience equivalent to qualifications acquired during the above academic course; (2) signed employment agreement (or preliminary employment agreement) with the prospective employer for a period of at least 1 year; (3) salary level-currently PLN 5 675,19 per month-approx. EUR 1,400 (the amount may change each year); Another condition is that the foreigner's remuneration may be no less than 150 per cent of the average remuneration (4) labour market test: entity intending to employee the applicant must be unable to satisfy its demand for personnel on the basis of the local labour market; this condition is lifted in certain cases, e.g., if the applicant has been previously legally employed with the same employer and in the same position; (5) health insurance valid in the territory of Poland; (6) additional regulatory requirements in case of certain regulated professions.

\section{Hungary}

In Hungary, Blue Card permits are rarely requested and issued. For example, in 2014 only one Blue Card permit was issued. Probably the main reason of this is that Hungary introduced a national regime for issuing joint 
residency and work permits for third-country nationals, which is similar to the EU Blue Card application system. The most significant difference between the EU Blue Card and the national regimes is that Blue Card permits are issued for a four year period, while national permits are issued for two years only, and national permits do not qualify workers for the simplified Blue Card proceedings in other EU countries. It seems that the longer term and the easier access to other member states are not attractive benefits to those who apply for work and residency permits in Hungary.

Not only the workers, but their employers may also apply for Blue Card on behalf of their workers in case the employer concluded a Strategic Partnership Agreement with the Hungarian Government, or the employer makes an investment, which is of high importance from Hungarian national economic purposes. Blue Card applications may be filed with any Hungarian consulate in the world and with the competent immigration authorities in Hungary as well. In Hungary, the salary threshold is 1.5 times the average gross salary (appr. EUR 1,200). In the healthcare sector, the salary threshold is 1.2 times the average gross salary. Hungary took the opportunity offered by the Directive and verifies during the Blue Card permit proceedings whether the concerned job vacancy could not be filled by national or EU workforce, or by third-country national already lawfully resident in Hungary. The length of Blue Card proceedings is 90 days.

\section{Acknowledgements}

The country summaries were prepared thanks to the information provided by: Karl Waheed (France), Pieter Krop (The Netherlands), Bettina Offer (Germany), Ana Garicano (Spain), Bernard Caris (Belgium), Elmar Drabek (Austria), David Kiss (Hungary), Karolina Schiffter (Poland).

\section{References}

Council

Directive.

(2009/50).

Retrieved

from

http://eur-lex.europa.eu/legal-content/EN/TXT/?uri=CELEX:32009L0050

EU Commission - Communication to the Parliament on the implementation of Directive. (2009). Retrieved from http://www.europarl.europa.eu/meetdocs/2014_2019/documents/com/com_com(2014)0287_/com_com(201 4)0287_en.pdf

EU Commission-Inception Impact Assessment-Review of Directive. (2009/50). Retrieved from http://ec.europa.eu/smart-regulation/roadmaps/docs/2016_home_025_review_eu_blue_card_directive_en.p df

EU Commission-Questions and Answers: An improved EU Blue Card scheme and the Action Plan on Integration. Retrieved from http://europa.eu/rapid/press-release_MEMO-16-2071_en.htm

International Organization for Migration-Global Migration Trends. (2014). Retrieved from http://mmp.iom.int/sites/default/files/Global-migration-trends_December-2014_final.pdf

McKinsey Global Institute-The world at work: jobs, pay and skills for 3.5 Billion people. (2012). Retrieved from file://C:/Users/Marco.Mazzeschi/Downloads/MGI\%20Global_labor_Full_Report_June_2012.pdf

OECD-International Migration Outlook. (2016). Retrieved from http://www.oecd.org/migration/international-migration-outlook-1999124x.htm

\section{Copyrights}

Copyright for this article is retained by the author(s), with first publication rights granted to the journal.

This is an open-access article distributed under the terms and conditions of the Creative Commons Attribution license (http://creativecommons.org/licenses/by/4.0/). 